\section{Menuju Masyarakat Urban: Sejarah Pendatang di Kota Jakarta Pasca Kemerdekaan (1949-1970)}

Oleh:

\section{Rahadian Ranakamuksa Candiwidoro ${ }^{1}$}

\begin{abstract}
Abstrak
Setelah kembalinya Ibukota Indonesia dari Yogyakarta ke Jakarta pada tahun 1949, kehidupan kota Jakarta berubah drastis. Telah terjadi pertumbuhan penduduk secara signifikan yang diakibatkan oleh perpindahan penduduk secara massal (urbanisasi) di Jakarta yang datang dari wilayah luar Jakarta. Para pendatang ini datang ke Jakarta untuk mencari kehidupan yang lebih layak karena Jakarta dianggap sebagai sebuah kota harapan. Periode 1949 hingga 1970 adalah periode yang penting untuk melihat betapa krusialnya pengaruh kedatangan para pendatang dalam membangun kota Jakarta sebagai sebuah kota metropolitan seperti sekarang ini. Penelitian ini menggunakan metode sejarah dengan menekankan pada analisis yang bersifat deskriptif untuk menjelaskan sejarah kota, yaitu Jakarta. Kajian ini menghasilkan tiga analisis sejarah mengenai pengaruh pendatang dalam pembentukan Jakarta sebagai kota metropolitan. Pertama adalah momentum sejarah dimana berlangsung gelombang pendatang baru yang komposisinya lebih beragam daripada masa sebelumnya sehingga mempengaruhi tingkat heterogenitas kota. Kedua adalah momentum sejarah yang menunjukkan perubahan gaya hidup dan cara adaptasi para pendatang ke dalam kehidupan masyarakat urban. Ketiga adalah transformasi sosial yang juga melahirkan adanya gentrifikasi dimana para pendatang mengalami kehidupan yang tidak layak
\end{abstract}

${ }^{1}$ Rahadian Ranakamuksa Candiwidoro adalah sejarahwan dan alumni Departemen Sejarah, Fakultas Ilmu Budaya UGM. Penulis pernah menjadi pemimpin utama Jurnal Ilmu Sejarah, Histma 2012-2014. sehingga melahirkan permasalahan sosial bagi kota Jakarta.

Kata kunci : pendatang, gentrifikasi, sejarah urbanisasi

\section{Abstract}

After the return of Indonesian capital city from Yogyakarta to Jakarta in 1949, the city's life changed dramatically. The population growth occurred significantly caused by mass population especially due to the migration of people who came from other regions outside of Jakarta (urbanization). These migrants came to Jakarta in order to seek a better life because Jakarta was considered as a city of hope. The period from 1949 to 1970 is an important historical phase that explains on the influence of migrants in building Jakarta as a metropolitan and multicultual city as we have seen today. This study uses historical method with emphasis on descriptive analysis in order to provide the history of Jakarta as a city. The study provides three historical analysis of the migrant influence in building Jakarta as a metropolitan city. First is the historical moment of a massive flow of newcomers which compositions were more diverse than in the past and thus had affected the city's heterogenity. Second is the historical moment of changing lifestyle especially when the migrants should be able to adapt to the urban life. Third is social transformation which also resulted in the gentrification of migrant living condition and thus became a social problem for the city.

Keywords: migrants, gentrification, history of urbanization

\section{Latar Belakang}

Setelah kembalinya ibukota pemerintahan RI dari Yogyakarta ke Jakarta pada tahun 1949, Jakarta bekembang menjadi kota pusat dari segala pusat aktivitas di 
Jurnal Pemikiran Sosiologi Volume 4 No. 1, Januari 2017

Rahadian Ranakamuksa Candiwidoro

Menuju Masyarakat Urban: Sejarah Pendatang di Kota Jakarta Pasca Kemerdekaan (1949-1970)

Indonesia. Segala urusan perdagangan, perniagaan dan pemerintahan terpusat di Jakarta. Sebagai ibukota pemerintahan yang baru, Jakarta pada akhirnya menerima investasi pendanaan pembangunan kota dalam skala yang lebih besar dibanding kota-kota lainnya di Indonesia untuk mencukupi segala kebutuhannya. Investasi ini dipergunakan untuk membangun infrastruktur-infrastruktur kota seperti gedung-gedung pemerintahan dan membangun pemukiman. Hal ini sebenarnya telah dimulai sejak awal masa kemerdekaan RI, sebagai contoh, hampir dua pertiga dari total pinjaman Pemerintah Republik Indonesia pada 1956 diberikan kepada Jakarta (Susan Blackburn, 2011: 247).

Pada tahun 1950, penduduk Jakarta berjumlah 1.600 .000 jiwa dan pada tahun 1960 jumlah tersebut telah bertambah hingga mencapai 2.900 .000 jiwa. Angka ini berkembang terus sampai mencapai lebih dari 4 juta jiwa pada akhir tahun 60-an. Pada 1953, sebuah survey di distrik-distrik tertentu di kota bagian dalam menunjukkan bahwa 75 persen penduduk disana merupakan warga kelahiran luar Jakarta. Dari jumlah ini, setengahnya bermigrasi ke Jakarta sejak 1949 (Susan Blackburn, Ibid: 259). Dari jumlah populasi yang begitu amat besar, kota Jakarta sama bervariasinya dengan Batavia pada abad ke-18, namun proporsi orang non-Indonesia sudah sangat berkurang. Hal ini menjadi menarik untuk diteliti lebih jauh karena jumlah para pendatang yang masuk ke Jakarta begitu sangat besar jumlahnya. Oleh karena itu tulisan ini berupaya untuk menjawab pertanyaan mengapa begitu banyak orang yang ingin datang ke Jakarta, darimana saja awalnya para pendatang ini berasal dan bagaimana para pendatang ini kemudian beradaptasi menjadi bagian dari warga Jakarta. Hal ini menarik untuk diketahui lebih lanjut dalam sejarah perkembangan sebuah kota.

\section{Metode dan Sumber Penelitian}

Penelitian ini merupakan penelitian sejarah kota yang dikembangkan dalam bentuk deskriptif-analitis. Selaras dengan tema yang digarap, yaitu tentang sejarah perkembangan kota, maka pendekatan yang digunakan adalah analisis sejarah yang menekankan aspek perkembangan sosialekonomi suatu kota. Untuk mengkaji perkembangan sejarah kota melalui pendekatan sosial-ekonomi metode analisis deskriptif dalam kajian sejarah dilakukan melalui langkah-langkah sebagai berikut (Kuntowijoyo, 2005: 98-104):

1. Mencari materi untuk dikerjakan atau mencari sumber informasi (heuristik). Pengumpulan data secara heuristik ini dilakukan dengan metode kepustakaan (literature research)

2. Penilaan terhadap materi sumber data dari sudut pandang nilai bukti (criticsm). 
Jurnal Pemikiran Sosiologi Volume 4 No. 1, Januari 2017

Rahadian Ranakamuksa Candiwidoro

Menuju Masyarakat Urban: Sejarah Pendatang di Kota Jakarta Pasca Kemerdekaan (1949-1970)

Tahap ini dikenal sebagai kritik atas sumber data melalui pendekatan kritik eksternal dan kritik internal.

3. Pernyataan resmi atas penemuan heuristik dan kritik, yang termasuk dalam tahap ini adalah kumpulankumpulan data sejarah dan presentasi yang diberikan (umumnya dalam bentuk tertulis), dimana disinilah akan muncul kebenaran objektif dan signifikan. Tahap ini adalah tahap sintesis dan eksposisi.

4. Interpretasi yakni terdiri dari analisis dan sintesis hasil dari interpretasi inilah akan menemukan fakta-fakta. Faktafakta inilah yang kemudian menjadi bahan penulisan dan siap disajikan dalam tulisan yang sistematis.

\section{Pembahasan}

\section{Awal Kedatangan Para Pendatang ke Jakarta}

Seiring kembalinya Pemerintah Republik Indonesia dari Yogyakarta ke Jakarta pada 1949, pertambahan penduduk di Jakarta mengalami kenaikan pesat. Kecenderungan ini berulang mengarah kepada kenaikan jumlah penduduk secara cepat. Angka resmi memperlihatkan berlipat gandanya populasi dari 823.000 jiwa pada 1948 menjadi 1.782.000 jiwa pada 1952 (Edy Sedyawati dkk, 1986: 46). Angka-angka ini sebenarnya juga melebih-lebihkan tingkat pertumbuhan awal jumlah penduduk kota Jakarta karena batas kota mengalami perubahan pada tahun 1950, Kotapraja
Jakarta Raya yang baru telah bertambah luasnya menjadi tiga kali lipat dari batas kota yang lama (sebelumnya). Perluasan wilayah ini adalah tanggapan terhadap pertumbuhan penduduk yang membawa kesadaran bahwa populasi perkotaan telah jauh melewati batas-batas lama kota dan sebagain besar daerah-daerah baru tersebut masih relatif jarang penduduknya. Sebagian besar populasi masih terkonsentrasi dalam batas kota yang lama. Selain perubahan batas kota, penyebab utama pertumbuhan populasi adalah besarnya migrasi masuk (in-migration) penduduk. Pada tahun 1948 dan 1949, jumlah penduduk Jakarta terus mengalami penambahan yang drastis yaitu 823.356 dan pada tahun 1949 yaitu menjadi 1.340.625. Pesatnya laju pertumbuhan penduduk ini sebagai akibat dari masuknya arus migrasi pertama yang terbesar dalam periode setelah kemerdekaan (Susan Blackburn, 2011: 255).

Mengapa mereka datang ke Jakarta? mereka datang dalam jumlah besar seiring dengan kembalinya Pemerintah Republik dari Yogyakarta ke Jakarta pada tahun 1949. Sebagai tempat kedudukan pemerintah yang baru Jakarta seperti menjanjikan bahwa kemerdekaan akan membawa kemakmuran, Jakarta nampaknya juga menawarkan harapan bagi para penduduk pedesaan. Banyak dari mereka yang datang dari wilayah-wilayah sangat padat di Jawa maupun luar Jawa. Jakarta dianggap sebagai 
Jurnal Pemikiran Sosiologi Volume 4 No. 1, Januari 2017

Rahadian Ranakamuksa Candiwidoro

Menuju Masyarakat Urban: Sejarah Pendatang di Kota Jakarta Pasca Kemerdekaan (1949-1970)

simbol repesentasi kemerdekaan sebuah bangsa yang merdeka, maka Jakarta dipandang bisa memberikan sebuah pengharapan akan siapapun yang datang ke Jakarta.

\begin{tabular}{|c|c|c|}
\hline \multicolumn{3}{|c|}{$\begin{array}{l}\text { Jumlah dan Pertumbuhan Penduduk } \\
\text { DKI JAKARTA } \\
\text { Tahun 1941-1960 }\end{array}$} \\
\hline Tahun & \begin{tabular}{|l} 
Jumlah \\
Penduduk
\end{tabular} & \begin{tabular}{|l} 
Laju \\
Pertumbuhan \\
Penduduk (\%)
\end{tabular} \\
\hline 1941 & 544.823 & 0,0 \\
\hline 1942 & 560.009 & 3,3 \\
\hline 1943 & 621.827 & 10,4 \\
\hline 1944 & 644.236 & 3,7 \\
\hline 1945 & 623.343 & $-3,3$ \\
\hline 1946 & \begin{tabular}{|l|}
601.904 \\
\end{tabular} & $-3,4$ \\
\hline 1947 & 599.821 & $-0,3$ \\
\hline 1948 & 823.356 & 37,2 \\
\hline 1949 & 1.340 .625 & 62,8 \\
\hline 1950 & 1.432 .085 & 6,8 \\
\hline 1951 & 1.661 .125 & 16,0 \\
\hline 1952 & 1.781 .723 & 7,3 \\
\hline 1953 & 1.795 .831 & 0,8 \\
\hline 1954 & 1.823 .918 & 1,6 \\
\hline 1955 & 1.884 .700 & 3,3 \\
\hline 1956 & 1.889 .618 & 0,3 \\
\hline 1957 & 1.945 .883 & 2,9 \\
\hline 1958 & 2.025 .909 & 4,1 \\
\hline 1959 & 2.881 .883 & 38,8 \\
\hline 1960 & 2.910 .858 & 3,5 \\
\hline
\end{tabular}

Tabel.1 Jumlah dan Pertumbuhan Penduduk Jakarta 1941-1960 (Sumber : KSS DKI Jakarta : Jakarta dalam angka 1984)

Pada awal periode tahun 50an menurut Nordholdt, nasionalisme sedang berada di puncak kejayaannya. Hal ini dilihat sebagai sebuah proyek budaya dengan pesan utama, "menjadi Indonesia berarti menjadi moderen." Di masa itu, modernitas bersinonim dengan nasionalisme (Henk Schulte Nordholt, 2011: 386. Lihat juga
Adrian Vickers, 2008). Pembangunan bangsa (nation-building) itu diantaranya terwujud dari diadakannya pembangunan yang didasarkan untuk mendekonstruksikan

simbol-simbol warisan kolonial. Imaji-imaji kolonial dihapuskan dari ingatan, untuk kemudian dibangun imaji-imaji baru yang bersifat "nasionalis". Monumen Van Heutz, Patung Jan Pieterszoon Coen, Patung Dewi Kebenaran di Taman Wilhemnia adalah contoh-contoh diantara monumen peninggalan kolonial yang dihancurkan pada masa itu untuk pembangunan Jakarta sebagai simbol nasionalisme bangsa Indonesia (Farabi Fakih, 2005: 124). Semangat-semangat semacam inilah yang ditengarai juga turut berperan dalam mendatangkan para pendatang ke Jakarta pasca kemerdekaan.

Sebagian lain orang datang ke Jakarta karena untuk menghindari kerusuhan di pedesaan yang terus berlanjut pasca awal kemerdekaan bahkan setelah perang dengan pihak Belanda berakhir. Di sejumlah wilayah di Jawa, para pemberontak mencoba melawan wewenang Pemerintah Republik. Di Jawa Barat misalnya, Darul Islam dianggap sebagai ancaman terbesar terhadap keteraturan dan ketertiban. Angkatan perang pemberontak muslim yang dipipmpin oleh Kartosuwiryo ini berperang demi mewujudkan sebuah Negara Islam dan menentang Republik Indonesia yang dianggap sekuler. 
Jurnal Pemikiran Sosiologi Volume 4 No. 1, Januari 2017

Rahadian Ranakamuksa Candiwidoro

Menuju Masyarakat Urban: Sejarah Pendatang di Kota Jakarta Pasca Kemerdekaan (1949-1970)

Pemberontakan kelompok ini berlangsung selama bertahun-tahun sejak pengalihan kedaulatan (Susan Blackburn, 2011: 278). Banyak orang yang pada akhirnya harus memilih untuk melarikan diri dari daerah wilayah konflik itu untuk menjadi pengungsi ke Jakarta atau kota-kota besar lainnya agar tidak dirampok maupun dibunuh oleh para gerilyawan Darul Islam ini.

Pada masa akhir perjuangan merebut kemerdekaan, kondisi ekonomi Indonesia sangat buruk. Produksi barang sangat rendah dan jumlah barang yang tersedia hanya sedikit. Keadaan ekonomi nasional mulai merosot ketika dimulainya Demokrasi Terpimpin oleh Presiden Soekarno. Perusahaan-perusahaan Belanda seperti bank, pabrik gula, penerbangan, kereta api, diambil alih oleh Pemerintah Indonesia. Terjadilah pengeluaran biaya negara dalam jumlah besar. Selain itu banyak pengangkatan pegawai negeri baru, serta biaya untuk perebutan Irian Barat yang saat itu masih diperjuangkan. Keuangan Negara menjadi defisit dan memaksa naiknya inflasi yang yang cukup drastis. Kebijakan tersebut sangat berpengaruh terhadap tingkat kemakmuran rakyat. Masalah besar yang paling menghantui rakyat adalah tingkat inflasi yang tinggi. Kondisi pasar semakin menurun, karena uang tidak lagi berlaku dalam nominal yang rendah (Thee Kian Wie, 2002: 377).
Hal tersebut juga dirasakan hingga ke desadesa. Kemandekan ekonomi di desa menyebabkan pertumbuhan penduduk mencapai tingkat yang sangat tinggi. Pertambahan penduduk yang tinggi disertai dengan pendapatan yang rendah telah memaksa makin banyak penduduk desa mencari jalan lain untuk meningkatkan taraf hidupnya. Pesatnya pertumbuhan penduduk Indonesia menyebabkan tekanan pada rasio lahan dan manusia meningkat yang kemudian mendorong terjadinya fragmentasi kepemiikan lahan, ketimpangan distribusi pemilikan lahan disertai dengan meningkatnya tunakisma atau petani yang tidak lagi memiliki lahan pertanian (Thee Kian Wie, 2002: 377). Di pedesaan kemiskinan berkorelasi tinggi dengan penguasaan lahan pertanian. Kenyataannya di pedesaan Jawa hampir 60 persen penduduknya tidak memliki lahan, sedangkan rata-rata luas pemilikan lahan (termasuk sawah dan lahan kering) hanya 0,62ha menurut sensus pertanian 1973 (Memed Gunawan dan Erwidodo, 1993). Hal itulah yang menyebabkan kurangnya lapangan pekerjaan di desa-desa karena terbatasnya lahan pertanan.

Bersamaan dengan kurangnya lapangan pekerjaan di luar sektor pertanian, tingginya tingkat kemisikian telah mendorong penduduk desa bermigrasi ke kota dalam upaya mencari alternatif dan pekerjaan dengan upah yang lebh tinggi. Apalagi di kota besar seperti Jakarta 
Jurnal Pemikiran Sosiologi Volume 4 No. 1, Januari 2017

Rahadian Ranakamuksa Candiwidoro

Menuju Masyarakat Urban: Sejarah Pendatang di Kota Jakarta Pasca Kemerdekaan (1949-1970)

membutuhkan kesempatan kerja yang lebih besar misalnya seperti di sektor industri (Michael P. Todaro dan Jerry Stilkind, 1983: 19). Tampak bahwa tidak lama setelah itu mulai terjadi gelombang masuk kota, yang tidak hanya distimulasi oleh meluasnya industri, tetapi juga oleh kondisi yang menyedihkan di wilayah pedesaan. Banyak sekali petani yang tidak mempunyai tanah pada akhirnya harus berduyun-duyun ke kota untuk mencari pekerjaan.

Sebagai Ibukota, pusat pemerintahan dan perdagangan, Jakarta menunjukkan pembangunan yang cukup mengesankan. Dengan adanya pembangunan yang demikian pesat maka besar pulalah perluasan kesempatan kerja. Perluasan kesempatan kerja inilah yang menjadi daya tarik bagi mereka yang telah merasa adanya dorongan untuk meninggalkan tempat asalnya. Daya tarik Jakarta sebagai ibukota negara atau pusat pemerintahan dan pusat ekonomi tentu menjadi magnet bagi warga di luar Jakarta untuk datang ke kota ini. Keahlian atau kemampuan seseorang di bidang pekerjaan yang dikuasai mutlak diperlukan bagi mereka yang memutuskan Jakarta sebagai tempat tinggal sekaligus tempat bekerja, baik sebagai buruh industri maupun pekerja kantor atau di bidang professional lain. Namun tidak semua lapangan kerja yang tersedia di Jakarta dapat menyerap warga pendatang dari luar Jakarta. Keahlian saja belumlah cukup untuk meraih pekerjaan yang diinginkan oleh warga pendatang karena dibutuhkan lagi keuletan, kesabaran dan kreativitas dalam pekerjaan yang ditekuni. Banyak yang diantara mereka pada akhirnya tidak terserap ke dalam angkatan kerja yang lantas harus bekerja di sektor informal. Ribuan lainnya yang tidak terdata adalah para migran musiman yang hanya tinggal selama beberapa bulan di kota, lalu kembali ke desa masing-masing pada masa bercocok tanam dan saat lebaran. Kemudian adapula para komuter yang menggunakan kereta api dan bis untuk pergi bekerja di Jakarta pada pagi hari.

"Sebenarnya pada tahun 1950-an Jakarta masih menjadi daerah yang menakutkan, belum banyak orang luar yang berani datang ke Jakarta karena banyak kriminal. Tapi di berbagai tempat memang sudah terkenal ramai seperti Tanjung Priuk, Rawa Belong, dan Senen" (Lihat Lamijo:10).

Pada awal 1950-an, sebagaimana dicatat seksi ketatanegaraan pemerintah umum kotapradja Djakarta raya disebutkan bahwa jumlah penduduk Jakarta mencapai 1.845.592 jiwa dengan jumlah penduduk terbanyak tinggal di kecamatan Mangga Dua yaitu sebanyak 400.618 jiwa (Lihat artikel "Berapa Sebetulnja Djumlah Penduduk Ibukota?,1952). Untuk kepadatan penduduk per hektar, pada 1957 misalnya, kepadatan penduduk di wilayah Menteng, Salemba, Tanah Abang, dan Kota mencapai 250 jiwa per hektar. Kepadatan penduduk di suatu wilayah per hektar di Jakarta terus 
Jurnal Pemikiran Sosiologi Volume 4 No. 1, Januari 2017

Rahadian Ranakamuksa Candiwidoro

Menuju Masyarakat Urban: Sejarah Pendatang di Kota Jakarta Pasca Kemerdekaan (1949-1970)

meningkat dari tahun ke tahun. Pemerintah

Jakarta mengalami kesulitan untuk mendata dan menata penduduk yang tinggal di kota ini, meskipun setiap tahunnya ada upaya membatasi jumlah warga yang datang ke kota ini. Namun kebijakan pemerintah Jakarta seperti tidak membuahkan banyak hasil dalam upaya menekan pertambahan penduduk. Pemerintah kota metropolitan ini kerap kali disibukkan oleh masalah kependudukan yang tidak kunjung tuntas dari tahun ke tahun.

\section{Jakarta sebagai Sebuah Masyarakat Campuran}

Jakarta atau dulu dikenal sebagai Batavia, sejak berabad-abad ditempati oleh beragam etnis dari berbagai daerah di Indonesia maupun luar negeri. Mereka datang, tinggal dan kemudian menetap karena berbagai alasan dan tujuan. Jumlah pendatang ini dari tahun ke tahun terus bertambah, seiring perkembangan Jakarta sebagai pusat pemerintahan dan perdagangan. Arus deras migrasi penduduk dari luar Jakarta ini kian sulit dibendung oleh Pemerintah Jakarta, bahkan hingga kini. Akan tetapi komposisi penduduk Jakarta telah banyak berubah, khususnya banyak penduduk keturunan Eropa yang pergi dari Jakarta karena berbagai macam hal. Berdasarkan Konferensi Meja Bundar pada 1949, orang Eropa diberi waktu dua tahun untuk memutuskan apakah ingin menjadi warga negara Indonesia atau tidak. Mayoritas orang Eropa tersebut memilih menjadi warga negara Belanda, kemudian meninggalkan Indonesia dengan bantuan permerintah Belanda. Rasa takut akan kehilangan status dan pendapatan dalam Republik Indonesia, ditambah insentif finansial dari Belanda sepertinya telah menentukan nasib orang-orang Eropa ini. Pada tahun 1956, jumlah orang Belanda di Jakarta kurang dari 17.000 jiwa. Setelah gerakan anti-Belanda terus menerus diteriakkan oleh pemerintah Indonesia, ditambah penolakan Belanda untuk menyerahkan Irian Barat, hanya tinggal 530 jiwa orang Belanda di Jakarta pada tahun 1961 (Susan Blackburn, 2011: 255). Gerakan anti-Belanda ini mencoba untuk menyingkirkan orang-orang asing dari posisi dominannya. Keputusan ini sangat sulit bagi banyak orang Eropa, khususnya Belanda yang sebenarnya juga menganggap Indonesia (Hindia Belanda) sebagai tanah kelahiran mereka.

Lalu ada juga warga yang memiliki keturunan Cina diharuskan untuk memilih kewarganegaran ketika terjadi sinisme terhadap warga asing. Etnis non pribumi terbanyak yang tinggal di Jakarta pada 1950-an adalah masih tetap keturunan Cina. Sudah sejak lama mereka merupakan penduduk minoritas terbesar di Jakarta. Menurut sensus tahun 1961, jumlah penduduk keturunan Cina sebesar 294.000 jiwa atau 10,1 persen dari seluruh penduduk Jakarta (Edy Sedywati, 1986: 47). 
Jurnal Pemikiran Sosiologi Volume 4 No. 1, Januari 2017

Rahadian Ranakamuksa Candiwidoro

Menuju Masyarakat Urban: Sejarah Pendatang di Kota Jakarta Pasca Kemerdekaan (1949-1970)

Jumlah yang cukup besar ini dikarenakan seluruh penduduk keturunan Cina di Indonesia tidak lebih dari tiga persen. Di Jakarta sendiri mereka mudah sekali ditemukan di pemukiman lama kota tua Jakarta seperti di daerah Glodok, Pinangsia dan sekitarnya yang merupakan daerah pecinan di Jakarta. Sebagian besar lagi bisa ditemui di Pasar Senen, Pasar Jatinegara, Pasar Tanah Abang dan beberapa daerah pertokoan lainnya yang masih bisa dilihat keberadaannya hingga sekarang. Karena kebanyakan dari mereka adalah pedagang atau pengusaha yang membuka toko dan usaha maka tidak heran ketika mereka biasa dijumpai di wilayah pertokoan maupun pasar.

Jumlah orang Cina di Jakarta setelah kemerdekaan lebih besar daripada sebelum perang. Pertambahan ini bukan melalui migrasi dari luar negeri seperti pada abadabad sebelumnya. Namun karena banyaknya pendatang dari daerah-daerah pinggiran yang merasa kehidupannya tidak aman. Keamanan menjadi isu sensitif bagi masyarakat Cina yang tinggal di Indonesia. Karena pada saat Indonesia telah memproklamirkan sebagai bangsa yang merdeka, banyak orang Cina yang dituduh tidak mendukung perjuangan kemerdekaan Indonesia. Akibatnya berbagai diskrimanasi dialami oleh orang Cina. Sebenarnya, setelah Indonesia berdiri, UU (Undangundang) Kewarganegaraan Indonesia yang menyangkut orang-orang asing (termasuk orang Cina) sudah cukup akomodatif. Apabila mereka yang tinggal di Indonesia pada waktu kemerdekaan tidak menyatakan menolak, setelah dua tahun mereka otomatis dianggap sebagai warga negara Indonesia. Namun, UU Kewarganegaraan ini, khususnya bagi orang Cina, lama kelamaan malah dipersulit. Hal ini disebabkan oleh antipati terhadap orang-orang Cina meningkat. Mereka dituduh sebagai kelompok yang sulit berasimilasi dan eksklusif oleh orang pribumi karena distigma cenderung mementingkan diri sendiri.

Diskrimanasi terhadap orang-orang Cina pun semakin banyak terjadi pada paruh 1950an. Pada era ini, ruang gerak ekonomi mereka dibatasi antara lain dengan keluarnya PP (peraturan pemerintah) No. 10 pada tahun 1959 oleh pemerintah Indonesia. Peraturan ini menyatakan bahwa orang Cina dilarang tinggal dan menjalankan usaha di wilayah pedesaan (Firman Lubis, 2008: 77). Pada 1961 masalah ini berdampak pada peningkatan jumlah orang Cina yang menjadi penduduk tetap di Jakarta, dimana hampir dua pertiga orang Cina (Tionghoa) di Indonesia yang memilih menjadi warga negara Indonesia memilih menetap disana. Sebagian orang Cina lainnya dari masa Hindia Belanda memilih kembali ke daratan Cina dan menjadi warga negara Republik Rakyat Cina (RRC). Jumlah mereka yang memilih kembali ke daratan Cina pada masa awal 
Jurnal Pemikiran Sosiologi Volume 4 No. 1, Januari 2017

Rahadian Ranakamuksa Candiwidoro

Menuju Masyarakat Urban: Sejarah Pendatang di Kota Jakarta Pasca Kemerdekaan (1949-1970)

kemerdekaan cukup banyak yakni sekitar 136.000 orang (Firman Lubis, 2008: 77).

\begin{tabular}{|c|c|c|}
\hline \multicolumn{3}{|c|}{$\begin{array}{l}\text { Komposisi Penduduk Jakarta } \\
\text { Berdasarkan Etnisitas } 1961\end{array}$} \\
\hline $\begin{array}{l}\text { Kelompok } \\
\text { Etnis }\end{array}$ & Jumlah & $\%$ \\
\hline Betawi & \begin{tabular}{|l|}
655.400 \\
\end{tabular} & 22,9 \\
\hline Sunda & 352.500 & 32,8 \\
\hline $\begin{array}{l}\text { Jawa dan } \\
\text { Madura }\end{array}$ & \begin{tabular}{|l|}
737.700 \\
\end{tabular} & 25,4 \\
\hline Minangkabau & \begin{tabular}{|l|}
60.100 \\
\end{tabular} & 2,1 \\
\hline $\begin{array}{l}\text { Sumatera } \\
\text { Selatan }\end{array}$ & 34.900 & 1,2 \\
\hline Batak & 28.900 & 1,0 \\
\hline Sulawesi Utara & 21.000 & 0,7 \\
\hline $\begin{array}{l}\text { Maluku dan } \\
\text { Papua }\end{array}$ & 11.800 & 0,4 \\
\hline Aceh & 5.200 & 0,2 \\
\hline Banjar & 4.800 & 0,2 \\
\hline $\begin{array}{l}\text { Nusa Tenggara } \\
\text { Timur }\end{array}$ & 4.800 & 0.2 \\
\hline Bali & 1.900 & 0,1 \\
\hline Tidak diketahui & 38.600 & 1,3 \\
\hline Cina & \begin{tabular}{|l|}
294.000 \\
\end{tabular} & 10,3 \\
\hline $\begin{array}{l}\text { Lain-lain (non } \\
\text { Pribumi) }\end{array}$ & 16.500 & 0,6 \\
\hline TOTAL & \begin{tabular}{|l|}
2.906 .500 \\
\end{tabular} & 100 \\
\hline
\end{tabular}

Tabel.2 Komposisi Penduduk Jakarta Berdasarkan suku bangsa pada tahun 1961 (Sumber : Lance Castle, 2007:60)

Jakarta terdiri dari berbagai kelompok etnis yang sangat banyak jumlahnya. Hebatnya para pendatang dalam jumlah besar yang datang ke Jakarta ini dapat segera menjadi orang Jakarta. Namun mereka masih dapat dibedakan berdasarkan sejumlah ciri khas kelompok etnis tertentu. Banyak pendatang dari luar pulau Jawa yang biasanya memiliki pendidikan lebih baik menjadi elit intelektual Jakarta. Orang-orang Batak Kristen membangun gereja-gereja dan melatih paduan suara mereka yang terkenal dan ada sebuah kelompok sandiwara Sunda bernama Miss Tjitjih yang telah lama melakukan pertunjukan keliling di teaterteater utama Jakarta dengan gaya yang sangat dipengaruhi kesenian stambul. Namun yang lebih hebat lagi adalah kemampuan para pendatang cepat beradaptasi dengan kehidupan kota. Sebagai contoh mereka sepertinya sudah mempelajari bahasa Indonesia yang digunakan sebagai bahasa resmi dan pergaulan di Ibukota. Pada gilirannya nanti, diperkirakan bahwa anak-anak para pendatang Jakarta tidak lagi mengidentifikasikan diri mereka dengan kelompok etnis orangtua mereka melainkan menganggap diri mereka sebagai penduduk asli Jakarta karena merasa telah dilahirkan disana. Bahasa Indonesia kemudian menjadi bahasa ibu anak-anak pendatang ini, bukan lagi bahasa daerah orang tua mereka masing-masing.

Pada saat itu tidak ada kelompok etnis yang mendominasi di Jakarta, sehingga semua harus belajar berkompromi untuk kepentingan hidup bersama. Tjalie Robinson menyebutnya sebagai kebudayaan gado-gado Jakarta, makanan yang dapat dipersiapkan dengan segala 
Jurnal Pemikiran Sosiologi Volume 4 No. 1, Januari 2017

Rahadian Ranakamuksa Candiwidoro

Menuju Masyarakat Urban: Sejarah Pendatang di Kota Jakarta Pasca Kemerdekaan (1949-1970)

macam sayuran dicampur dengan saus kacang pedas (Susan Blackburn, 2011: 277). Bagi sejumlah pendatang baru, kelonggaran budaya yang sepertinya tanpa akar di Jakarta nampak tidak dapat dicerna. Namun bagi sebagian besar orang, toleransi ini sepertinya tumbuh dari keyakinan terhadap kemampuan Jakarta untuk menghadapi keberagaman. Ini tentu saja ciri kebudayaan yang penting dalam kehidupan di kota metropolitan. Hubungan penduduk Jakarta antara satu suku dengan suku lainnya relatif cukup rukun. Konflik kesukuan jarang terjadi di Jakarta meski beragam suku tinggal bersama di kota ini. Sedikit gesekan tentu tidak bisa dihindarkan ketika para pendatang mulai membuat pertahanan diri di kota yang keras ini dengan membuat ikatan dari sesama suku. Ikatan antar suku menguat lantaran para pendatang mesti bertahan hidup karena tidak masuk kedalam angkatan kerja dibidang formal. Banyak dari pendatang ini yang akhirnya harus saling sikut demi sebuah pekerjaan informal seperti pedagang kecil, sopir, buruh musiman, tukang bensin eceran, tukang becak, pemulung dll.

Pada tahun 1950-an Firman Lubis mengatakan bahwa sensitifitas yang didasari oleh sentimen atau stigma buruk antar etnis belum ada pada waktu itu, kalaupun ada pasti sangat kecil. Bahkan katanya lagi, jika membuat lelucon menggunakan perumpamaan berdasarkan etnis seseorang yang bersangkutan tidak akan marah bahkan ikut tertawa bersama (Firman Lubis, 2008: 77). Masalah etnisitas pada waktu itu belum menjadi isu yang sensitif seperti pada waktu dulu Jakarta masih bernama Batavia. Para pendatang yang datang ke Jakarta dengan motif untuk mencari pekerjaan biasanya lebih memilih untuk tinggal dimana mayoritas etnis mereka secara berkelompok bertempat tinggal atas dasar kebersamaan dan kedekatan. Pada periode tahun 50an hingga 70 an beberapa sumber tertulis mengatakan bahwa walaupun sulit untuk memetakan kantung-kantung kecil etnis yang tersebar, namun hampir bisa dipastikan bahwa mereka membentuk kantung-kantung etnis seperti yang terjadi di sekitar kawasan Pasar Senen (Lihat Lance Castels, 2007: 94 dan Abdul Chaer, 2012: 122). Fenomena kantung-kantung etnis tersebut mulai bermunculan ketika orang-orang yang datang ke Jakarta merasa membutuhkan teman untuk sama-sama berjuang untuk melanjutkan hidup di tanah yang baru mereka kunjungi. Akhirnya karena merasa masih saudara satu etnis, mereka memutuskan untuk bertempat tinggal di satu daerah atau kawasan yang sama.

Meskipun pendatang dari berbagai etnis di Indonesia dalam dekade terakhir terus berlangsung dalam jumlah yang besar, perkembangan tersebut tidak menyebabkan terbentuknya suatu pemukiman berdasakan suku atau etnis. Akan tetapi semakin berjalannya waktu dan tidak ada 
Jurnal Pemikiran Sosiologi Volume 4 No. 1, Januari 2017

Rahadian Ranakamuksa Candiwidoro

Menuju Masyarakat Urban: Sejarah Pendatang di Kota Jakarta Pasca Kemerdekaan (1949-1970)

lagi keharusan untuk tinggal dimana etnis mereka bermukim seperti pada kurunkurun waktu sebelumnya, membuat berbagai kelompok yang menetap di berbagai penjuru kota ini kemudian memilih tempat tinggal yang sesuai dengan berdasarkan pekerjaan dan status sosial ekonomi mereka. Pada tahun 1961, sebenarnya pemukiman penduduk yang konsentrasinya berdasarkan etnis atau ras masih ada, walaupun data sensus sampai sejauh ini tidak cukup mengidentifikasikan wilayah pemukiman berdasarkan asal-usul para pendatang secara jelas. Orang India mayoritas tinggal di wilayah Sawah Besar yang letaknya berdekatan dengan Pasar Baru walaupun banyak diantara mereka yang akhirnya juga meninggalkan Indonesia. Lalu ada orang Indonesia Timur terkonsentrasi di tanjung Priuk, terutama orang Bugis dan Makasar. Terdapat juga orang-orang Indonesia Timur yang beragama Kristen, terutama orang Ambon dan Manado yang pemukimannya terkonsentrasi di wilayah Gambir (Lance Castles, 2007: 90).

Makin beragamnya etnis yang menetap di Jakarta juga berarti makin banyak orang dengan latar belakang budaya yang berbeda. Hal tersebut juga berarti bahwa kemungkinan terjadi gesekan antar etnis menjadi semakin besar. Konflik yang terjadi biasanya merupakan persoalan kecil dan jarang sampai masuk ke berita elektronik maupun cetak, sehingga menyulitkan untuk mendata kapan saja konflik antar etnis terjadi. Pada periode ini juga konflik yang terjadi antar etnis hanya sekedar konflik kecil. Konflik yang terjadi lebih banyak berasal dari persaingan untuk memperebutkan pekerjaan. Persaingan tersebut terjadi karena merasa sudah jauhjauh datang ke Jakarta untuk mencari pekerjaan dan kehidupan yang lebih baik. Salah satu alasan mengapa orang dari berbagai penjuru Indonesia begitu mudah menyesuaikan diri di Jakarta adalah bantuan yang mereka terima ketika mulai menjalani kehidupan di Jakarta. Sebagian besar pendatang ke Jakarta disambut oleh teman dan kerabat yang memberi saran kepada mereka sebelum mereka mengambil keputusan untuk melakukan migrasi (Susan Blackburn, 2011: 255). Jadi sepertinya pada masa setelah kemerdekaan, para pendatang baru telah mengetahui bahwa mereka harus mempelajari bahasa baru yaitu bahasa Indonesia dan menyesuaikan diri ke dalam masyarakat kosmopolitan. Kenalan para pendatang telah membantu mereka dalam hal ini dan mencarikan pekerjaan serta memberikan tempat tinggal sementara ketika pertama kali baru datang di Jakarta. Kemampuan adaptasi semacam itulah yang memungkinkan mereka untuk dapat berasimilasi sebagai penduduk kota.

Banyak kelompok etnis bahkan memiliki asosiasi atau kelompok-kelompok etnis mereka sendiri di Jakarta untuk membantu para pendatang baru dalam beradaptasi, 
Jurnal Pemikiran Sosiologi Volume 4 No. 1, Januari 2017

Rahadian Ranakamuksa Candiwidoro

Menuju Masyarakat Urban: Sejarah Pendatang di Kota Jakarta Pasca Kemerdekaan (1949-1970)

bahkan mengajarkan etika setempat.

Misalnya orang-orang Batak yang terbiasa bersuara keras diberitahu untuk mengurangi kebiasaan mereka agar lebih mudah diterima. Akan tetapi di sisi lain sebuah kajian terhadap kampung pekerja di Jakarta menujukkan cara lain bagaimana pendatang menetap di kota dan belajar hidup bersama dengan orang-orang dari kelompok etnis yang berbeda. Dalam kasus ini, lingkungan yang dipelajari adalah perumahan yang disediakan untuk para pekerja Djawatan Kereta Api Republik Indonesia. Kampung ini dihuni oleh para pendatang baru dari Jawa Tengah dan Jawa Timur yang tinggal di bangunan-bangunan asrama dan memiliki tempat kerja yang sama. Kerja bersama-sama membantu menciptakan ikatan kelompok baru antar etnis. Orang-orang yang datang belakangan akan bertanya pada mereka yang telah tinggal di kampung itu lebih dulu sebelumnya. Hal yang sama kemungkinan terjadi di wilayah permukiman lainnya yang dibangun oleh pemerintah maupun industri.

Namun sejak awal periode tahun 50an sampai 60an, Jakarta yang dibanjiri oleh para pendatang dari luar pada akhirnya menghadapi kenyataan pesatnya pertumbuhan penduduk. Akibat migrasi migrasi yang pesat ini juga berdampak pada persaingan kerja dan ketimpangan antar kelas sosial sehingga memunculkan permasalahan baru seperti gentrifikasi atau wilayah yang mengalami keadaan ruang hidup yang sulit dan kumuh.

\section{Gentrifikasi dan Para Pendatang Baru Yang Terus Berdatangan ke Jakarta}

Ikatan kekeluargaan serta komunikasi diantara para pendatang dengan mereka yang berada di daerah asalnya banyak menarik kedatangan para pendatang baru. Meski demikian, persoalan baru muncul terutama terjadinya proses gentrifikasi dimana para pendatang baru yang tidak selalu berhasil dalam kehidupannya yang baru di kota justru hidup dalam kondisi miskin dan lingkungan yang kumuh. Meski demikian, gelombang para pendatang baru terus terjadi pada periode tahun 1970an. Kalau ada pendatang yang berhasil dalam kehidupannya di Jakarta maka ia akan menarik saudara dan kenalannya sekampung untuk ikut mengadu untung. Hubungan demikian saling terjalin bersamaan dengan harapan memperoleh pekerjaan menjadi daya tarik bagi para pendatang (Morgan Oey, 1977: 70).

Jumlah dan Presentase Pendatang ke DKI Jakarta Menurut Daerah Asal 1961-1971

\begin{tabular}{|l|l|l|}
\hline Daerah Asal & $\begin{array}{l}\text { Jumlah } \\
\text { Pendatang }\end{array}$ & $\%$ \\
\hline Jawa Barat & 382.500 & 37,4 \\
\hline Jawa Tengah & 281.354 & 27,5 \\
\hline Jawa Timur & 84.499 & 8,3 \\
\hline Sumatera Utara & 46.546 & 4,5 \\
\hline Sumatera Barat & 42.134 & 4,1 \\
\hline
\end{tabular}


Jurnal Pemikiran Sosiologi Volume 4 No. 1, Januari 2017

Rahadian Ranakamuksa Candiwidoro

Menuju Masyarakat Urban: Sejarah Pendatang di Kota Jakarta Pasca Kemerdekaan (1949-1970)

\begin{tabular}{|c|c|c|}
\hline $\begin{array}{l}\text { Sumatera } \\
\text { Selatan }\end{array}$ & 34.283 & 3,4 \\
\hline D.I. Yogyakarta & 38.297 & 3,1 \\
\hline Sulawesi Selatan & 20.632 & 2,1 \\
\hline $\begin{array}{l}\text { Kalimantan } \\
\text { Barat }\end{array}$ & 14.438 & 1,4 \\
\hline Riau & 9.703 & 0,9 \\
\hline Sulawesi Utara & 9.252 & 0,9 \\
\hline Luar Negeri & 8.120 & 0,8 \\
\hline Lampung & 6.812 & 0,7 \\
\hline D.I. Aceh & 6.422 & 0,6 \\
\hline Maluku & 5.294 & 0,5 \\
\hline $\begin{array}{l}\text { Kalimantan } \\
\text { Selatan }\end{array}$ & 5.294 & 0,5 \\
\hline Jambi & 5.126 & 0,5 \\
\hline Bali & 3.670 & 0,4 \\
\hline NTT & 3.056 & 0,3 \\
\hline $\begin{array}{l}\text { Kalimantan } \\
\text { Timur }\end{array}$ & 2.943 & 0,28 \\
\hline Sulawesi Tengah & 2.698 & 0,26 \\
\hline Bengkulu & 2.642 & 0,25 \\
\hline Irian Barat (Jaya) & 2.473 & 0,29 \\
\hline NTB & 2.137 & 0,18 \\
\hline $\begin{array}{l}\text { Sulawesi } \\
\text { Tenggara }\end{array}$ & 1.878 & 0,16 \\
\hline $\begin{array}{l}\text { Kalimantan } \\
\text { Tengah }\end{array}$ & 952 & 0,09 \\
\hline TOTAL & 1.022 .796 & 100 \\
\hline
\end{tabular}

Tabel.3 Jumlah dan Presentase Pendatang ke DKI Jakarta 1961-1971 (Sumber : BPS. Sensus Penduduk 1971. BKLH DKI Jakarta 1984: 32)

Pada tahun 1961, tak sampai setengah dari jumlah penduduk dilahirkan di Jakarta, akan tetapi jumlah itu meningkat pada tahun 1971, dimana 60 persen penduduk dilahirkan di Jakarta. Pada periode inilah sebenarnya jumlah para pendatang baru terus berdatangan sebenarnya tidak lebih banyak dari periode sebelumnya seperti di awal tahun 60an. Meski demikian, pada tahun 70an pendatang baru yang terus berdatangan ini sekarang lebih beragam etnisitasnya dari seluruh penjuru negeri. Pada tabel 3 di atas memperlihatkan bahwa seluruh daerah di Indonesia merupakan tempat asal para pendatang. Itu berarti seluruh propinsi di Indonesia sejak tahun 1961 telah menyumbangkan pendatang ke kota Jakarta. Diketahui juga bahwa mayoritas para pendatang di Jakarta berasal dari daerah yang dekat. Lima propinsi yang terbanyak menyumbangkan pendatang kepada Jakarta adalah Jawa Barat, Jawa Tengah, Jawa Timur, baru kemudian dari luar Jawa seperti Sumatera Utara, dan Sumatera Barat. Tentu tidak kebetulan bahwa kelima daerah tersebut mewakili empat kelompok etnis yang memiliki kebudayaan yang berbeda-beda, yaitu Sunda (Jawa Barat), Jawa (Jawa Tengah dan Jawa Timur), Batak (Sumetera Utara), dan Minangkabau (Sumatera Barat). Hal ini tidak terlepas dari pembangunan jaringan trasnportasi yang memadai seperti bis dan kereta api yang sebenarnya telah ada sejak masa kolonial. Berbagai macam solusi telah dilakukan oleh pemerintah kota Jakarta untuk mengatasi masalah kepadatan penduduk yang terjadi di Jakarta ini. Salah satunya adalah melaui program Keluarga Berencana (KB) dan transmigrasi. Tetapi 
Jurnal Pemikiran Sosiologi Volume 4 No. 1, Januari 2017

Rahadian Ranakamuksa Candiwidoro

Menuju Masyarakat Urban: Sejarah Pendatang di Kota Jakarta Pasca Kemerdekaan (1949-1970)

program ini tidak terlalu disukai oleh warga Jakata. Usaha lain untuk membendung pendatang yang menambah kepadatan penduduk ini sebenarnya sudah dilakukan pada tahun 1968 yaitu dengan dimulainya aturan yang mengharuskan para pendatang baru itu untuk memenuhi ketentuanketentuan tentang pendaftaran kelahiran, kematian dan kewajiban penduduk untuk memegang Kartu Tanda Penduduk (KTP).

Solusi yang paling menggemparkan akibat luapan migrasi ke Jakarta adalah keputusan Gubernur Ali Sadikin yang menyatakan Jakarta sebagai "kota tertutup" bagi para pendatang. Pada tahun 1970, ia mengumumkan bahwa semua warga harus membawa kartu tanda penduduk (KTP) dan hanya mereka yang dapat membuktikan identitasnya sebagai penduduk tetap yang diizinkan tinggal dan bekerja di Jakarta. Aparat dan otoritas keamanan kemudian sering melakukan razia untuk mengumpulkan para pendatang yang baru berdatangan ke Jakarta dan bahkan mengembalikan mereka ke daerah asal sebagai akibat dari ketentuan itu. Pada saat itu pula dimulailah operasi pembersihan jalanan dari orang-orang yang tidak memiliki kartu tanda penduduk (KTP) ini. Operasi-operasi razia semacam ini cenderung menyasar para pendatang yang memiliki pekerjaan di sektor informal khususnya yang berbasis di jalanan seperti tukang becak dan pedagang keliling. Ada dua alasan mendasar mengapa pemerintah kota tidak menyukai pekerjaan semacam ini. Pertama, pekerjaan-pekerjaan ini menampung pendatang dalam jumlah besar dengan menyediakan berbagai macam pekerjaan mandiri yang hanya membutuhkan sedikit keahlian atau modal. Pemerintah beranggapan bahwa jika pekerjaan ini semacam ini dapat dikurangi, maka pendatang akan berkurang. Kedua, para pekerja ini dianggap tidak sesuai dengan gambaran pembanguan kota Jakarta sebagai citra kota metropolitan yang baru. Para penarik becak yang memenuhi jalan dianggap memperlambat aliran lalu lintas kendaraan bermotor dan memperlihatkan secara sekilas gambaran yang memalukan atas pembangunan teknologi moderen di Indonesia (Susan Blackburn, 2007: 312).

Pada akhir 1960an, terdapat sejumlah 92.650 becak yang terdaftar secara resmi di Jakarta, dan secara tidak resmi jumlahnya diperkirakan mencapai 150.000. Sebagai lagkah pertama menghapus becak, pada tahun 1970 Ali Sadikin melarang pembuatan becak baru. Setahun kemudian, ia mulai membatasi daerah-daerah operasi becak. Polisi melakukan penggerebekan terhadap becak-becak yang berada di daerah terlarang dan menyita kendaraannya. Ali Sadikin berkomentar sebagai berikut;

"Saya sangat ingin menunjukkan kepada para pendatang baru bahwa hidup di Jakarta tidak enak. Hidup di Jakarta itu sangat susah"

(Susan Blackburn, Ibid : 313) 
Jurnal Pemikiran Sosiologi Volume 4 No. 1, Januari 2017

Rahadian Ranakamuksa Candiwidoro

Menuju Masyarakat Urban: Sejarah Pendatang di Kota Jakarta Pasca Kemerdekaan (1949-1970)

Seperti Pemerintah kota Jakarta sebelumnya, Gubernur Sadikin khawatir jika mayoritas pendatang dari daerah pedesaan ini tidak dapat menyesuaikan diri di Kota Metropolitan. Oleh sebab itu ia mengeluarkan kebijakan berupa SK Gubenur Kepala Daerah Khusus Ibukota Jakarta No. Ib/3/I/27/ tentang keberadaan Jakarta sebagai kota tertutup bagi para pendatang dari luar Jakarta 70 ( Edy Sedyawati, 1986: 83) Meski kebijakan itu sebenarnya bukan untuk melarang mobilitas warga, namun keputusan tersebut sering ditafsirkan sebagai larangan menjadi penduduk DKI Jakarta. Walaupun pada awalnya cukup ditakuti, namun nampaknya kebijakan ini juga tidak terlau berdampak signifikan. Pemalsuan Kartu Tanda Penduduk (KTP) biasa terjadi dan banyak orang yang terus menampung pada pendatang baru ini. Walaupun langkah ini dipandang sebagai langkah baru yang sangat besar dalam manajemen perkotaan, kenyataanya kebijakan "Jakarta sebagai Kota Tertutup" tidak dapat efektif dijalankan karena pendatang baru terus berdatangan apapun alasan dan tujuannya.

\section{Kesimpulan}

Setelah kemerdekaan Indonesia tercapai, dimulailah proses migrasi para pendatang yang berlangsung secara cepat dan massif. Jakarta dianggap sebagai simbol repesentasi kemerdekaan sebuah bangsa yang merdeka, maka Jakarta dipandang bisa memberikan sebuah pengharapan akan siapapun yang datang ke Jakarta. Kota ini dicitrakan seakan-akan sebagai sebuah kota harapan dimana membawa kehidupan yang lebih baik. Pada saat itu keadaan ekonomi juga sedang memburuk karena memang negara yang merdeka itu baru saja terbentuk. Transisi dari masa kolonial ke masa berdirinya Indonesia sebagai suatu negara bangsa baru juga berdampak pada kemorosotan ekonomi yang membuat orang-orang dari desa khususnya, tidak memiliki pekerjaan yang layak untuk menghidupi dirinya sendiri dan pergi ke kota. Situasi keamanan dan ancaman terjadinya konflik di wilayah-wilayah pedalaman membuat banyak pendatang dari luar harus pergi meninggalkan desanya lantaran dihantui perampokan dan pembunuhan.

Kehidupan di kota Jakarta juga membuat dari pendatang ini harus cepat beradaptasi dengan kehidupan kota Jakarta. Pada awal kedatangannya ke Jakarta, para pendatang ini ditampung oleh mereka yang berasal dari daerah yang sama seperti para pendatang. Lantaran ikatan-ikatan kesamaan inilah yang membuat mereka dapat memasuki kehidupan di Jakarta. Banyak juga dari pendatang ini yang segera ditampung oleh sanak saudaranya yang telah terlebih dahulu memasuki kota Jakarta. Keadaan ini membuat Jakarta kelebihan beban untuk menampung 
Jurnal Pemikiran Sosiologi Volume 4 No. 1, Januari 2017

Rahadian Ranakamuksa Candiwidoro

Menuju Masyarakat Urban: Sejarah Pendatang di Kota Jakarta Pasca Kemerdekaan (1949-1970)

penduduk melampaui batas-batas yang sudah direncanakan. Akan tetapi di sisi lain, karena para pendatang ini datang dari berbagai macam penjuru di Nusantara maka terciptalah sebuah komposisi penduduk yang beragam dari berbagai etnis daripada masa-masa sebelumnya. Hal ini membuat Jakarta menjadi kota yang memiliki tingkat heterogenitas yang baik untuk menciptakan suatu tatanan baru bagi kehidupan kota Jakarta. Wujud Jakarta dengan keragaman penduduknya itu juga yang kemudian menjadikan kota ini berkembang mengikuti jalannya modernisasi kota, sehingga perkembangan wilayah pemukiman di kota Jakarta lebih berdasarkan pembedaan kelas sosial ketimbang berdasarkan pada pengelompokan etnisitas.

\section{DAFTAR PUSTAKA}

Blackburn, Susan. 2011. Jakarta: Sejarah 400 Tahun. Jakarta: Komunitas Bambu

Chaer, Abdul. 2012. Folklore Betawi: Kebudayaan dan Kehidupan Orang Betawi. Jakarta: Masup Jakarta.

Castels, Lance. 2007. Profil Etnik Jakarta. Jakarta: Masup Jakarta.

Fakih, Farabi. 2005. Membayangkan Ibukota Jakarta di bawah Soekarno. Yogyakarta: Penerbit Ombak.

Gunawan, Memed, dan Erwidodo. 1993. 'Urbanisasi dan Pengurangan Kemisikian : Kasus Migrasi DesaKota di Jawa Barat'. Prisma No.3 /1993.
Kuntowijoyo, 2005. Pengantar Ilmu Sejarah, Yogyakarta: Benteng Pustaka.

Lubis, Firman. 2008. Jakarta 1960-an: Kenangan Semasa Mahasiswa. Jakarta: Masup Jakarta.

Nordholt, Henk Schulte ,dkk. 2008. Perspektif Baru Penulisan Sejarah Indonesia. Jakarta: Yayasan Obor.

Oey,Morgan. 1977. 'Jakarta Dibangun Kaum pendatang'. Prisma 5 Mei 1977

Sedyawati, Edi, dkk 1986. Sejarah Kota Jakarta 1950-1980, Jakarta: Departemen Pendidikan dan Kebudyaan, Direktorat Sejarah dan Nilai-Nilai Tradisional, Proyek Inventarisasi dan Dokumentasi Sejarah Nasional

Thee, Kian Wie. 2002. 'Kebijakan Ekonomi Indonesia Selama Periode 19501965', dalam Thomas Lindblad (ed), Fondasi Historis Ekonomi Indonesia. Yogyakarta: Pustaka Pelajar.

Todaro, Michael dan Stilkind, Jerry. 1983. Dilemma Urbanisasi dalam Urbanisasi, Pengangguran, dan Sektor Informal di Kota. Jakarta: Yayasan Obor

Vickers, Adrian. 2008. Mengapa tahun 1950an penting bagi kajian Indonesia dalam Prespektif Baru Penulisan Sejarah Indonesia Jakarta: Yayasan Obor.

Sumber Internet:

Lamijo, Prostitusi di Jakarta Dalam Tiga Kekuasaan 1930-1959, Sejarah dan Perkembangannya. Diakses melalui laman internet http:// sejarah.fib.ugm.ac.id

Sumber Lain:

KSS DKI Jakarta : Jakarta dalam Angka 1984

Arsip Surat Kabar:

Pedoman, 12 Desember 1952: "Berapa Sebetulnja Djumlah Penduduk Ibukota?" (tanpa keterangan penulis) 